\title{
ANALISIS CEMARAN MIKROBA PADA DAGING AYAM BROILER DI BEBERAPA PASAR KOTA AMBON
}

\author{
Isye J. Liur*, Astri D. Tagueha \\ Jurusan Peternakan, Fakultas Pertanian, Universitas Pattimura \\ J1. Ir. M. Putuhena, Kampus Poka, Ambon 97233 \\ *Email : isye.liur@faperta.unpatti.ac.id
}

\begin{abstract}
ABSTRAK
Daging ayam merupakan salah satu pangan yang digemari masyarakat karena memiliki kandungan gizi yang tinggi, rasa yang enak, harga yang terjangkau juga tekstur serat yang lunak sehingga mudah dicerna. Kandungan gizi yang tinggi dapat menjadikan daging ayam sebagai media yang baik untuk pertumbuhan dan perkembangan mikroorganisme. Penelitian dilakukan bertujuan untuk mengetahui jumlah kontaminasi bakteri pada daging ayam yang dijual pada beberapa pasar di kota Ambon. Penelitian ini menggunakan metode eksperimen yaitu analisa cemaran mikroba pada sampel daging ayam yang tersebar di Kota Ambon. Penelitian diawali dengan mengambil sampel ayam bagian dada dan paha dari berbagai pasar di kota Ambon. Sampel yang digunakan adalah daging ayam yang telah disimpan selama 2 hari. Selanjutnya dilakukan tahap isolasi bakteri. Hasil penelitian menunjukkan bahwa cemaran mikroba pada sampel bagian dada dan paha daging ayam masih dibawah batas maksimum (kurang dari $1 \mathrm{x}$ $10^{6} \mathrm{cfu} / \mathrm{g}$ ) yang ditentukan oleh Badan Standarisasi Nasional. Daging ayam broiler di Kota Ambon aman untuk dikonsumsi oleh masyarakat.
\end{abstract}

Kata kunci: Daging ayam broiler, cemaran mikroba, pasar kota Ambon

\section{ANALYSIS OF MICROBIAL CONTAMINATION IN BROILER MEAT IN SOME MARKETS OF AMBON CITY}

\begin{abstract}
Chicken meat is one of the foods favored by the public because it has high nutritional content, delicious taste, affordable prices, and a soft fiber texture that makes it easy to digest. The high nutritional content can make chicken meat a good medium for the growth and development of microorganisms. The research was conducted to determine the amount of bacterial contamination in broiler meat sold in several markets in Ambon city. This study used an experimental method, namely the analysis of microbial contamination in the famous chicken meat sample in Ambon City. The research was started by taking samples of chicken breasts and thighs from various markets in Ambon city. The sample used was chicken meat that had been stored for 2 days. Furthermore, the bacterial isolation stage is carried out. The results showed that the microbial contamination in the sample of chicken breasts and thighs was still below the maximum limit (less than 1 x $10^{6} \mathrm{cfu} / \mathrm{g}$ ) determined by the National Standardization Agency. Broiler chicken meat in Ambon City is safe for consumption by the public.
\end{abstract}

Key words: Broiler meat, microbial contamination, Ambon market

\section{PENDAHULUAN}

Daging ayam merupakan salah satu pangan yang digemari masyarakat karena selain rasanya yang enak, juga memiliki kandungan gizi yang tinggi, dengan harga yang terjangkau. Selain itu, daging ayam broiler memiliki tekstur serat yang lunak sehingga mudah dicerna, akibatnya masyarakat umumnya lebih memilih daging ayam sebagai sumber protein hewani dibandingkan dengan daging sapi dan kambing. Menurut Statistik Ditjen PKH (2018), pada tahun 2017, konsumsi nasional per kapita per tahun untuk daging sapi sebesar 0,46 kg, daging kambing sebesar 0,05 kg, sedangkan daging ayam broiler sebesar 5,68 kg. Dengan kebutuhan protein yang harus dipenuhi, maka dalam konteks keamanan pangan khususnya daging ayam, menjadi penting untuk mendapat daging yang sehat dan kandungan gizi yang tinggi. Daging ayam dikatakan berkualitas baik apabila jumlah bakteri kontaminan tidak melebihi batas maksimum yang ditentukan oleh SNI (2009) yaitu sebesar1 x $10^{6} \mathrm{cfu} / \mathrm{g}$.

Kandungan gizi yang tinggi menjadikan daging ayam sebagai bahan pangan yang mudah mengalami kerusakan. Menurut Afrianti dkk. (2013), daging ayam 
dapat mengalami kerusakan secara biologis. Daging ayam dapat menjadi media yang baik untuk pertumbuhan dan perkembangan mikroorganisme terutama karena kandungan air dan proteinnya yang tinggi selain vitamin dan mineral, sehingga dapat menyebabkan kebusukan daging yang berpengaruh terhadap kualitas daging ayam (Suardana \& Swacita. 2009). Selain itu, sumber kontaminan juga berasal dari lingkungan produksi, distribusi dan atau pasar, maupun para pekerja. Kontaminasi mikroba pada daging semakin cepat bila didukung oleh kondisi lingkungan yang tidak bersih. Proses penyimpanan dan distribusi daging yang tidak sesuai standar dapat menyebabkan terjadinya kontaminasi pada daging ayam (Sukmawati dkk., 2018). Pencemaran mikroba dapat terjadi karena adanya kontaminasi langsung atau tidak langsung dengan sumber-sumber pencemaran mikroba, seperti tanah, udara, air, debu, saluran pencernaan dan pernafasan manusia maupun hewan (Aerita dkk., 2014).

Menurut Soeparno (2009), kontaminasi mikroba pada daging dimulai sejak berhentinya peredaran darah pada saat penyembelihan, terutama apabila alat-alat yang digunakan untuk pengeluaran darah tidak higienis dan steril. Selanjutnya Utari dkk. (2016), menyatakan bahwa kontaminasi dapat terjadi melalui permukaan daging selama operasi persiapan daging beku, pemotongan karkas atau daging, pembuatan produk daging olahan, preservasi, pengepakan, penyimpanan, dan distribusi. Jadi, segala sesuatu yang dapat kontak dengan daging secara langsung atau tidak langsung, bisa merupakan sumber kontaminasi mikroba.

Suhu dan lama penyimpanan dapat berpengaruh terhadap kualitas daging. Semakin lama daging disimpan maka semakin cepat terjadi pertumbuhan bakteri. Tanda-tanda kerusakan pada daging adalah terjadinya perubahan warna, adanya lendir, timbulnya bau busuk dan terjadi perubahan rasa yang disebabkan oleh oksidasi lemak daging (Afrianti dkk., 2013). Daging ayam yang disimpan dengan suhu ruang maupun penyimpanan dingin dengan waktu yang relatif lama akan memungkinkan terjadinya kontaminasi oleh mikroba yang menyebabkan penurunan kualitas mutu (Sangadji dkk., 2019). Daging yang sudah terkontaminasi mikroba dapat menjadi sumber penyakit dan membahayakan kesehatan konsumen. Kontaminasi pada daging berawal dari masuknya mikroba pada saat penyembelihan dikarenakan peralatan yang digunakan tidak bersih. Selain itu tempat penyimpanan yang tidak memadai juga merupakan penyebab terjadinya kontaminasi.

Kota Ambon memiliki beberapa pasar yang sering dikunjungi oleh masyarakat untuk berbelanja kebutuhan pangan sehari-sehari termasuk daging ayam broiler. Pasar merupakan tempat bertemunya penjual dan pembeli dengan lingkungan yang tidak bersih sehingga pasar beresiko terhadap cemaran mikroba. Penyediaan daging ayam segar harus mendapat perhatian khusus karena sifatnya yang mudah rusak, sehingga untuk memperoleh kualitas daging ayam yang baik harus memenuhi standar mutu menurut standar nasional Indonesia (SNI). Berdasarkan hal tersebut, maka sampai sejauh mana tingkat kontaminasi atau cemaran mikroba terhadap daging ayam broiler yang dijual di pasar Kota Ambon menjadi penting untuk diteliti. Dengan demikian pada akhirnya dapat diketahui jumlah kontaminasi bakteri pada daging ayam broiler yang dijual di pasar kota Ambon sebagai upaya untuk menjaga mutu daging ayam broiler supaya aman dikonsumsi oleh masyarakat.

\section{BAHAN DAN METODE}

Bahan dan alat yang digunakan selama penelitian yaitu daging ayam, akuades, tablet Kjeldahl, kultur bakteri: plate count agar (PCA), lauryl tryptose broth (LTB), brilliant green lactose bile broth (BGLB), labu Kjeldahl (Pyrex), buret (Pyrex), cawan porselen (Haldenwanger), penjepit, timbangan analitik, soxhlet, Erlenmeyer (Pyrex), kertas saring (Whatman), beaker gelas (Pyrex), saringan, refrigerator, blender, cawan petri, timbangan (Sonic), tabung reaksi (Pyrex), penghitung koloni serta alat penunjang mikrobiologi lainnya.

Penelitian ini dilakukan selama dua (2) bulan, menggunakan daging ayam broiler bagian dada dan paha yang dipilih dan diambil secara acak (random sampling) dari lima (5) lokasi pasar yang berbeda (Benteng, Mardika, Passo, Rumahtiga, dan Batu Merah) di kota Ambon. Dari masing-masing lokasi pasar, diambil 3 sampel sebagai ulangan, sehingga total sampel penelitian sebanyak 15 sampel. Semua lokasi ini dipilih dengan pertimbangan menjadi lokasi yang lebih sering dikunjungi masyarakat untuk membeli ayam. Teknik pengambilan sampel yang digunakan adalah simple random sampling. Kemudian sampel tersebut dimasukkan ke dalam plastik steril yang diberi label per masing-masing sampel dengan lokasi yang berbeda dan dimasukkan ke dalam coolbox, kemudian dibawa ke laboratorium untuk selanjutnya dilakukan pengujian tingkat kontaminasi mikrobiologi terhadap daging ayam broiler.

Pengamatan yang dilakukan pada daging ayam yaitu analisa mikrobiologi meliputi angka lempeng total (TPC). Pengujian dilakukan di Laboratorium Balai Riset dan Standarisasi Industri (Baristand) Ambon. Sampel selanjutnya dilakukan tahap isolasi bakteri dengan cara melakukan pengenceran dan menginokulasikan $1 \mathrm{~mL}$ suspense dari setiap pengenceran ke dalam cawan petri yang berisi media Plate Count Agar (PCA) secara duplo dengan menggunakan metode agar tuang (Sukmawati, 2017). Biakan kemudian diinkubasi selama 24 jam dan dilakukan penghitungan mikroba total menggunakan colony counter.

Data yang diperoleh ditabulasi, kemudian dianalisis, dan diuraikan secara deskriptif untuk mendapatkan kesimpulan sesuai tujuan penelitian yaitu aman atau tidak sampel untuk dikonsumsi. 


\section{HASIL DAN PEMBAHASAN}

Daging yang mengalami kerusakan mengandung mikroba perusak termasuk bakteri yang bersifat patogen. Jumlah dan jenis mikroba pada pangan dipengaruhi oleh faktor intrinsik (di antaranya kandungan gizi, pH, kadar air, protein), dan faktor ekstrinsik (di antaranya suhu, kelembaban, waktu dan keberadaan oksigen). Data hasil penelitian menunjukkan bahwa jumlah koloni tertinggi sampel bagian paha sebesar $1,42 \times 10^{4} \mathrm{cfu} . \mathrm{g}$ dan sampel bagian dada sebesar 2,08 x 104 cfu.g terdapat pada pasar Mardika, dan terendah pada sampel bagian paha sebesar $2,12 \times 10^{3} \mathrm{cfu}$.g dan bagian dada sebesar $1,87 \times 10^{3} \mathrm{cfu} . \mathrm{g}$ terdapat pada pasar Benteng (Tabel 1). Hal ini diduga karena lokasi pengambilan sampel pada pasar Mardika kurang terjaga kebersihannya dibanding dengan pasar lainnya. Namun demikian jumlah kontaminasi mikroba ayam broiler di pasar Mardika tersebut tidak melebihi standar maksimum cemaran mikroba menurut SNI (2009), dimana standar jumlah angka lempeng total daging unggas menurut SNI (2009) adalah 1 x $10^{6} \mathrm{cfu}$.g.

Hasil pengamatan di lapangan terlihat dari lingkungan sekitar pasar Mardika yang kotor dan becek, tempat penjualan daging ayam juga tercampur dengan komoditi pangan maupun non pangan lainnya yang memungkinkan terjadinya kontaminasi mikroba. Selain itu para pedagang atau pekerja yang tidak memakai sarung tangan saat menangani daging ayam. Sedangkan pasar Benteng, memiliki tempat penjualan yang ditata

dengan baik dan rapi, dimana tempat menjual daging ayam terpisah dari jenis komoditi lainnya, dan para penjual atau pekerja menggunakan sarung tangan dalam menangani daging, sehingga jumlah mikoba yang mengkontaminasi daging lebih sedikit dibanding pasar lainnya.

Jumlah bakteri pada daging ayam dapat mengalami peningkatan seiring berjalannya waktu. Semakin lama daging terpapar udara dan berkontaminasi dengan udara, maka jumlah kontaminasi oleh mikroba akan meningkat. Menurut Ginting dkk. (2014) bahwa dengan bertambahnya waktu penyimpanan maka total mikroba pun akan semakin meningkat. Selanjutnya Gibson et al. (2018), menyatakan bahwa waktu generasi bakteri pendek, sehingga bakteri dapat tumbuh lebih banyak dalam waktu yang singkat.

Kandungan gizi yang terkandung dalam daging ayam juga merupakan salah satu faktor yang mempengaruhi jenis bakteri yang tumbuh pada daging ayam. Bakteri-bakteri kontaminan proteolitik dan lipolitik akan tumbuh dengan baik pada daging ayam, karena kandungan protein dan lemak daging ayam yang tinggi. Bakteri lipolitik antara lain: Pseudomonas fluorescens, Proteus sp., Enterobacter sakazaki, Campylobacter sp., dan Staphylococcus aureus, sedangkan bakteri proteolitik diantaranya Pseudomonas spp., Serratia spp., dan Morganella spp. (Rouger et al., 2017).

Tabel 1. Kontaminasi Mikroba Berdasarkan Jumlah Koloni Bakteri Pada Daging Ayam Broiler Di Kota Ambon

\begin{tabular}{lcc}
\hline \multicolumn{1}{c}{ Asal Sampel } & \multicolumn{2}{c}{ Rata-rata } \\
\cline { 2 - 3 } & Paha & Dada \\
\hline Pasar Benteng & $2,12 \times 10^{3} \mathrm{cfu} . \mathrm{g}^{-1}$ & $1,87 \times 10^{3} \mathrm{cfu} \cdot \mathrm{g}^{-1}$ \\
Pasar Mardika & $1,42 \times 10^{4} \mathrm{cfu} \cdot \mathrm{g}^{-1}$ & $2,08 \times 10^{4} \mathrm{cfu} \cdot \mathrm{g}^{-1}$ \\
Pasar Passo & $2,57 \times 10^{3} \mathrm{cfu} \cdot \mathrm{g}^{-1}$ & $2,21 \times 10^{3} \mathrm{cfu} \cdot \mathrm{g}^{-1}$ \\
Pasar Rumahtiga & $2,55 \times 10^{3} \mathrm{cfu} \cdot \mathrm{g}^{-1}$ & $2,67 \times 10^{3} \mathrm{cfu} \cdot \mathrm{g}^{-1}$ \\
Pasar Batu Merah & $3,40 \times 10^{3} \mathrm{cfu} \cdot \mathrm{g}^{-1}$ & $4,00 \times 10^{3} \mathrm{cfu} \cdot \mathrm{g}^{-1}$ \\
\hline
\end{tabular}

Hasil penelitian seperti tertera pada Tabel 1 menunjukkan daging ayam broiler yang dijual pada lima (5) pasar yang berbeda di Kota Ambon aman untuk dikonsumsi, karena masih berada di bawah batas maksimum yang ditentukan oleh Badan Standarisasi Nasional Indonesia. Tingkat cemaran mikroba ini tergolong rendah diduga karena sampel daging ayam broiler yang diteliti masih tergolong segar atau belum lama disimpan dari periode pemotongan.

Sebagai perbandingan, hasil penelitian Afrianti dkk. (2013), menunjukan tingkat cemaran mikroba daging ayam pada peternakan Boja Kabupaten

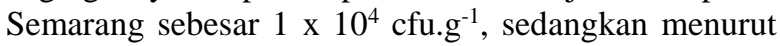
Matulessy dkk. (2010), nilai total mikroba karkas sampel dagung ayam dari pasar tradisional Kabupaten Halmahera Utara diketahui 7,1 x $10^{5}{\mathrm{cfu} . \mathrm{g}^{-1}}_{\text {yang }}$ menunjukkan bahwa jumlah bakteri berada di bawah batas maksimum cemaran menurut SNI. Sedangkan hasil penelitian yang dilaporkan oleh Ristanti dkk. (2017), bahwa total bakteri pada daging ayam di semua pasar Kabupaten Semarang berada di atas standar maksimum SNI. Selanjutnya berdasarkan penelitian Irmayani dkk. (2019), yang melaporkan sekitar $66 \%$ sampel daging ayam di Kota Pare-Pare melebihi batas standar SNI. Selain itu Ramadhani dkk. (2020), juga melaporkan bahwa seluruh sampel daging ayam broiler yang berasal dari pasar Banyumanik Kota Semarang tidak memenuhi persyaratan kualitas mikrobiologis daging ayam yang baik menurut SNI. Salah satu kemungkinan sumber kontaminasi adalah peralatan yang digunakan, selain kondisi higienis lingkungan.

Perbedaan tingkat kontamisasi mikroba berdasrkan jumlah koloni pada daging ayam dari lokasi pasar berbeda menunjukkan bahwa tingkat higienis, sanitasi, kondisi lingkungan, peralatan yang digunakan dan penyimpanan tidak sama pada tiap lokasi. 
Perbedaan jumlah koloni tiap sampel dapat dipengaruhi oleh beberapa faktor diantaranya adalah kondisi lingkungan, dimana faktor higienitas dan sanitasi para pekerja juga menjadi faktor utama. Mikroba yang mengkontaminasi daging umumnya berasal dari penggunaan air yang tercemar. Kontaminsi dapat terjadi akibat proses penanganan yang tidak baik.

Perbedaan jumlah koloni mikroba tiap sampel juga dapat dipengaruhi oleh suhu, baik pada waktu penyimpanan maupun pada proses distribusinya. Suhu merupakan salah satu faktor penting dalam perkembangan mikroba. Mikroba dapat berkembang dengan baik pada suhu ruang. Menurut Lawrie (2003) meningkatnya jumlah mikroorganisme pada suatu sampel juga dipengaruhi oleh faktor suhu. Selanjutnya menurut Hajrawati (2016), pertumbuhan dan aktivitas mikroba dipengaruhi oleh faktor suhu penyimpanan, waktu, tersedianya oksigen dan kadar air daging.

Karkas ayam yang telah dibersihkan harus diletakkan di tempat bersih dan terbebas dari debu maupun kotoran. Menurut Sartika dkk. (2016), meletakan karkas ayam yang telah dicuci langsung ke tempat yang kotor dapat menyebabkan kontaminasi yang bersumber pada bulu, darah, jeroan maupun kotoran. Selain itu, kondisi lingkungan yang tidak bersih dapat memungkinkan daging dihinggapi oleh lalat sebagai vektor pembawa mikroba (Afshari et al., 2018).

Lamanya sampel terpapar oleh udara juga menjadi faktor terjadinya kontaminasi akibat terjadinya pertumbuhan mikroba yang cepat. Semakin lama daging terpapar udara, maka mikroba yang tumbuh juga akan semakin banyak. Hasil penelitian Ristanti dkk. (2017), menemukan bahwa sampel daging ayam yang terpapar oleh udara selama 6 jam memiliki jumlah total mikroba yang lebih tinggi dari sampel daging ayam yang terpapar udara selama 4 jam.

Menurut Bakara (2014), daging ayam yang tercemar dapat berasal dari peternakan yang tercemar. Untuk mengurangi jumlah kontaminasi dapat menerapkan higienis dan sanitasi yang baik, dimana para pekerja menggunakan pakaian khusus dalam menangani daging ayam (Zakour, 2009). Dilanjutkan oleh Kurniadi dkk. (2013), sanitasi yang tidak memenuhi syarat dapat menjadi penyebab tercemarnya bahan pangan oleh mikroba.

Faktor higienis dan sanitasi merupakan faktor yang mempengaruhi terjadinya pertumbuhan dan aktifitas mikroba. Hasil penelitian Aerita dkk. (2014), menunjukkan bahwa higienis dan sanitasi tempat penjualan sangat mempengaruhi pertumbuhan mikroba pada daging ayam. Aspek higienis dan sanitasi harus mendapat perhatian yang baik oleh para pekerja maupun penjual untuk menghindari terjadinya kontaminasi. Langkah sederhana yang dapat dilakukan menurut Manning (2010) adalah mencuci tangan dengan air dan sabun sebelum dan sesudah menyiapkan daging dan mencuci kembali peralatan yang digunakan apabila akan digunakan lagi.
Proses pengolahan yang benar dapat menghambat pertumbuhan mikroba. Pengolahan dengan suhu panas dapat mematikan dan mengurangi jumlah mikroba. Dengan demikian konsumen dapat terhindar dari penyakit. Menurut Afshari et al. (2018), daging unggas yang dikonsumsi tanpa pengolahan yang benar dapat menimbulkan penyakit bagi yang mengkonsumsi.

\section{SIMPULAN}

Daging ayam broiler yang dijual pada beberapa pasar di Kota Ambon memiliki tingkat cemaran mikroba di bawah batas maksimum yang ditentukan oleh Badan Standarisasi Nasional Indonesia, sehingga tergolong aman untuk dikonsumsi.

\section{DAFTAR PUSTAKA}

Aerita, A. N., E. T. Pawenang, \& Mardiana. 2014. Hubungan Higiene Pedagang dan Sanitasi dengan Kontaminasi Salmonella pada Daging Ayam Potong. Unnes Journal of Public Health. 3(4): 9-16.

Afrianti,M., B. Dwiloka, \& B. E. Setiani. 2013. Total Bakteri, PH dan Kadar Air Daging Ayam Broiler Setelah Direndam dengan Ekstrak Daun Senduduk (Melastomamala Bathricum L.). Jurnal Pangan dan Gizi. 4(1): 49-56.

Afshari, A., A. Baratpour, S. Khanzade, \& A. Jamshidi. 2018. Salmonella enteritidis and Salmonella typhimorium Identification in Poultry Carcasses. Iran J. Microbiol. 10(1): 45-50.

Badan Standarisasi Nasional. 2009. SNI 3924 2009: Mutu Karkas dan Daging Ayam. Jakarta: Badan Standardisasi Nasional.

Bakara, V.F.S., M. Tahsin, \& Hasnudi. (2014). Analisis Bakteri Salmonella sp. pada Daging Ayam Potong yang Dipasarkan Pada Pasar Tradisional dan Pasar Modern Di Kota Medan. J. Peternakan Intergratif. 3(1): 71-83.

[Ditjen PKH] Direktorat Jenderal Peternakan dan Kesehatan Hewan. 2018. Statistik Peternakan dan Kesehatan Hewan. Jakarta: Kementerian Pertanian RI.

Gibson, B., D J. Wilson, E. Feil, \& A. Eyre-Walker. 2018. The Distribution of Bacterial Doubling Times In The Wild. Proc. of the Royal Society B: Biological Sciences. 285(1880):20180789. DOI: https://dx.doi.org/ 10.6084/m9.

Ginting, C., S. Ginting, \& I. Suhaidi. 2014. Pengaruh Jumlah Bubuk Kunyit Terhadap Mutu Tahu Segar Selama Penyimpanan Pada Suhu Ruang. Jurnal Rekayasa Pangan dan Pertanian. 2(4): 52-60. 
Hajrawati, M. Fadliah, Wahyuni, \& I. I. Arief. 2016. Kualitas Fisik, Mikrobiologis dan Organoleptik Daging Ayam Broiler Pada Pasar Tradisional Di Bogor. Jurnal Ilmu Produksi dan Teknologi Hasil Peternakan. 04(3): 386-389.

Irmayani, Rasbawati, I. D. Novieta, \& Nurliyani. 2019. Analisis Cemaran Mikroba dan Nilai pH Daging Ayam Broiler di Pasar Tradisional Lakessi Kota Pare-Pare. Jurnal Galung Tropika. 8(1): 1-8. DOI: http://dx.doi.org/10.31850/jgt.v8i1.431.

Kurniadi, Y., Z. Saam, \& D. Afandi. 2013. Faktor Kontaminasi Bakteri E. coli pada Makanan Jajanan di Lingkungan Kantin Sekolah Dasar Wilayah Kecamatan Bangkinang. Jurnal Ilmu Lingkungan. 7(1): 28-37.

Lawrie. 2003. Ilmu Daging (Penerjemah: A. Parakkasi dan Yudha A). Jakarta: Universitas Indonesia Press.

Manning, D. S. 2010. Escherichia coli Infection. New York: Chelsea House Pub.

Matulessy, N. D., E. Suryanto, \& Rusman. 2010. Evaluasi Karakteristik Fisik, Komposisi Kimia dan Kualitas Mikrobia Karkas Broiler Beku yang Beredar Di Pasar Tradisional Kabupaten Halmahera Utara, Maluku Utara. Jurnal Peternakan. 34(3): 178-185.

Ramadhani, W. M., I. Rukmi, \& S. N. Jannah. 2020. Kualitas Mikrobiologis Daging Ayam Broiler di Pasar Tradisional Banyumanik Semarang. Jurnal Biologi Tropika. 3(1): 8-16.

Ristanti, E.W., S. Kismiati, \& D. W. Harjanti. 2017. Pengaruh Lama Pemaparan pada Suhu Ruang Terhadap Total Bakteri, pH dan Kandungan Protein Daging Ayam Di Pasar Tradisional Kabupaten Semarang. Agromedia. 35(1): 50-57.
Rouger, A., O. Tresse, \& M. Zagorec. 2017. Bacterial Contaminants of Poultry Meat: Sources, Species, and Dynamics. Microorganisms. 5(50): 1-16. DOI: doi:10.3390/microorganisms5030050.

Sangadji, I., Jurianto, \& M. Rijal. 2019. Lama Penyimpanan Daging Ayam Broiler Terhadap Kualitasnya Ditinjau Dari Kadar Protein dan Angka Lempeng Total Bakteri. Jurnal Biology Science \& Education. 8(1): 47-58.

Sartika, D., Susilawati, \& G. Arfani. 2016. Identifikasi Cemaran Salmonella sp. pada Ayam Potong dengan Metode Kuantifikasi di Tiga Pasar Tradisional dan Dua Pasar Modern di Kota Bandar Lampung. Jurnal Teknologi Industri dan Hasil Pertanian. 21(2): 89-96.

SNI. 2009. Batas Maksimum Cemaran Mikroba dalam Pangan. SNI 7388:2009.

Soeparno. 2009. Ilmu dan Teknologi Daging. Cetakan Kelima. Yogyakarta: Gadjah Mada University Press.

Suardana, I. W., \& Swacita. 2009. Higiene Makanan. Bali: Udayana University Press.

Sukmawati. 2017. Identify of floc-forming bacteria in shrimp pond in Pangkep District. J. Bio Science. 1(2): $22-28$.

Sukmawati, R., \& A. Fahrizal. 2018. Analisis Cemaran Mikroba pada Daging Ayam Broiler di Kota Makassar. Scripta Biologica. 5(1): 51-53. DOI: https://doi.org/10.20884/1.SB.2018.5.1.799.

Utari, L. K., R. Riyanti, \& P. E. Santosa. 2016. Status Mikrobiologis Daging Broiler Di Pasar Tradisional Kabupaten Pringsewu. Jurnal Ilmiah Peternakan Terpadu. 4(1): 63-66.

Zakour, P. 2009. Good Manufacturing Practices. Dalam Heredia N, Wesley I, Garcia S, editor. Microbiologically Safe Foods. Mexico: Wiley.

Available online at journal homepage: http://ojs3.unpatti.ac.id/index.php/agrinimal 